Article

\title{
Anaplastic Thyroid Cancer: Clinical Picture of the Last Two Decades at a Single Oncology Referral Centre and Novel Therapeutic Options
}

\author{
Joana Simões-Pereira ${ }^{1,2,3, * \mathbb{C}}$, Ricardo Capitão ${ }^{4}$, Edward Limbert ${ }^{1}$ and Valeriano Leite ${ }^{1,2,3}$ \\ 1 Serviço de Endocrinologia, Instituto Português de Oncologia de Lisboa, Francisco Gentil, \\ Rua Professor Lima Basto, 1099-023 Lisboa, Portugal \\ 2 Unidade de Investigação em Patobiologia Molecular, Instituto Português de Oncologia de Lisboa, \\ Francisco Gentil, Rua Professor Lima Basto, 1099-023 Lisboa, Portugal \\ 3 Nova Medical School | Faculdade de Ciências Médicas da Universidade Nova de Lisboa, Campo Mártires da \\ Pátria, n. ${ }^{\circ}$ 130, 1169-056 Lisboa, Portugal \\ 4 Serviço de Endocrinologia, Hospital Egas Moniz, Centro Hospitalar Universitário Lisboa Ocidental, \\ Rua da Junqueira, n. ${ }^{\circ}$ 126, 1349-019 Lisboa, Portugal \\ * Correspondence: joanasimoespereira@gmail.com; Tel.: +351-217-229-800
}

Received: 2 July 2019; Accepted: 9 August 2019; Published: 15 August 2019

\begin{abstract}
Anaplastic thyroid cancer (ATC) is a rare tumour but also one of the most lethal malignancies. Therapeutic modalities have usually been limited, but clinical trials with new drugs are now being implemented. The aims of this study were to analyse the clinical presentation, therapeutic modalities and independent prognostic factors for survival. We also reviewed the most recent literature on novel ATC therapies. We performed a retrospective analysis of 79 patients diagnosed between 2000 and 2018. Variables with impact on survival were identified using the Cox proportional-hazard regression model. At presentation, 6.3\% had thyroid-confined disease, 30.4\% evidenced extrathyroidal extension and $60.8 \%$ were already metastatic. Surgery was feasible in $41.8 \%$ and radiotherapy was applied to $35.4 \%$, with those receiving $>45$ Gy having longer estimated survival $(p=0.020)$. Chemotherapy, either conventional or with tyrosine kinase inhibitors, was performed in $17.7 \%$ and $7.6 \%$, respectively. Multimodality therapy with surgery, radiotherapy and chemotherapy/tyrosine kinase inhibitors (TKI) had the greatest impact on disease specific survival (DSS), providing a risk reduction of death of $96.9 \%$ (hazard ratio (HR) $=0.031,0.005-0.210, p<0.001$ ). We concluded that most of these patients join reference centres at advanced stages of disease and multimodality treatment may offer the best chances for prolonging survival.
\end{abstract}

Keywords: anaplastic thyroid cancer; survival; tyrosine kinase inhibitors; immune checkpoint inhibitors

\section{Introduction}

Anaplastic thyroid cancer (ATC) is a rare tumour but accounts for more than $50 \%$ of all deaths attributable to thyroid tumours [1]. Undeniably, ATC is one of the most lethal malignancies in humans, as it portends a median survival of only three to four months and a disease-specific mortality at one year of nearly $100 \%$ [2]. ATC's loco-regional invasiveness may cause compressive symptoms, like dysphagia, dyspnoea, stridor and pain, and makes it usually inoperable. Therefore, this disease must be promptly recognized, in order to be managed in a specialized centre, by a multidisciplinary team with expertise in ATC, including endocrinologists, oncologists, surgeons, radiotherapists and pathologists [3]. 
Given its aggressiveness, the American Joint Committee on Cancer (AJCC) classifies all cases of ATC as stage IV: IVA describes all the tumours that are confined to the gland, IVB represents ATC with gross extrathyroidal extension and in stage IVC the tumour has already spread to distant sites [4]. The American Thyroid Association (ATA) guidelines [4] consider multimodal therapy with surgery, radiotherapy and/or chemotherapy, when feasible, as a reasonable approach in these cases; however, a significant proportion of the patients arrive to the health care centres at an advanced stage of disease and, to most of them, palliative and symptomatic care represent the wisest attitude to take.

Different from well-differentiated thyroid cancers (WDTC), ATC cells do not produce thyroglobulin, so there is no tumour marker for these tumours, and they do not respond to thyroid-stimulating hormone (TSH) suppression; furthermore, ATC cells do not uptake iodine, so radioiodine is ineffective in these patients [3]. Given the rarity of ATC, the studies analysing the impact of different therapeutic approaches are small and usually of a retrospective nature or they only report isolated cases. ATC is generally refractory to standard therapies, which renders these patients excellent candidates for innovative adjuvant therapies, including drugs targeting specific oncogenic mutations, tyrosine kinase inhibitors (TKI) and immune-modulating approaches [3].

The purpose of this study was to analyse the clinical presentation, therapeutic modalities and its outcomes, as well as the prognostic factors influencing disease specific survival (DSS), in a homogenous population of ATC followed at a single institution. Furthermore, we also reviewed the most recent literature on novel ATC therapies.

\section{Materials and Methods}

We performed a retrospective analysis of patients' clinical files with ATC diagnosed between 2000 and 2018 and followed at Instituto Português de Oncologia de Lisboa, Francisco Gentil, Lisboa, Portugal. ATC diagnosis was made from cytological or histological specimens and confirmed by experienced pathologists. Cases in which WDTC represented the main counterpart of the histological piece were excluded.

Patients were identified from the Endocrinology and Pathology database. Data regarding demographic characteristics, clinical presentation, therapeutic approaches and its outcomes, and survival were collected and registered with Microsoft Excel (Microsoft, Redmond, WA, USA).

DSS after ATC diagnosis was analysed using the Kaplan-Meier method and log-rank test. The independent prognostic factors were identified using the Cox proportional-hazard regression model. A $p$-value $<0.05$ was considered statistically significant. The statistical analysis was performed with IBM SPSS Version 23.

This study was approved by the Ethics Committee of Instituto Português de Oncologia de Lisboa Francisco Gentil (project number 1056).

\section{Results}

We included 79 patients, 53 (67.1\%) of which were women. The median age at diagnosis was 74 (interquartile range (IQR): 15 years). The main clinical characteristics and their impact on median survival are presented in Table 1. The incidence of new ATC diagnosis over the last two decades at our institution is represented in Figure 1.

Table 1. Clinicopathological characteristics.

\begin{tabular}{lccc}
\hline \multicolumn{1}{c}{ Characteristics } & No. $(\%)$ & Median Survival, mo & $p$-Value, Log-Rank Test \\
\hline Age & & & \\
$\leq 70$ years & $36(45.6 \%)$ & 2.0 & 0.514 \\
$\quad>70$ years & $43(54.4 \%)$ & 2.0 & \\
\hline Sex & & & \\
Female & $53(67.1 \%)$ & 2.0 & \\
Male & $26(32.9 \%)$ & 3.0 & \\
\hline
\end{tabular}


Table 1. Cont.

\begin{tabular}{|c|c|c|c|}
\hline Characteristics & No. $(\%)$ & Median Survival, mo & $p$-Value, Log-Rank Test \\
\hline \multicolumn{4}{|l|}{ Tumour dimensions } \\
\hline$\leq 60 \mathrm{~mm}$ & $32(40.5 \%)$ & 2.0 & 0.511 \\
\hline$>60 \mathrm{~mm}$ & $34(43 \%)$ & 2.0 & \\
\hline NA & $13(16.5 \%)$ & & \\
\hline \multicolumn{4}{|l|}{ Stage at diagnosis } \\
\hline IVA & $5(6.3 \%)$ & 9.0 & \\
\hline IVB & $24(30.4 \%)$ & 2.0 & 0.031 \\
\hline IVC & $48(60.8 \%)$ & 2.0 & \\
\hline NA & $2(2.5 \%)$ & & \\
\hline \multicolumn{4}{|l|}{ Leukocytosis } \\
\hline$<10,000 / \mathrm{mm}^{3}$ & $12(15.2 \%)$ & 1.0 & \\
\hline $10,000-20,000 / \mathrm{mm}^{3}$ & $44(55.7 \%)$ & 2.5 & 0.003 \\
\hline $20,000-30,000 / \mathrm{mm}^{3}$ & $12(15.2 \%)$ & 1.0 & \\
\hline$>30,000 / \mathrm{mm}^{3}$ & $4(5.1 \%)$ & 1.0 & \\
\hline NA & $7(8.9 \%)$ & & \\
\hline \multicolumn{4}{|l|}{ Diagnosis } \\
\hline Cytology & $36(45.6 \%)$ & 1.0 & 0.001 \\
\hline Histology & $43(54.4 \%)$ & 2.0 & \\
\hline \multicolumn{4}{|l|}{ Compressive symptoms } \\
\hline Yes & $68(86.1 \%)$ & 1.0 & 0.451 \\
\hline No & $9(11.4 \%)$ & 2.0 & \\
\hline NA & $9(11.4 \%)$ & & \\
\hline \multicolumn{4}{|c|}{ Previous or coexistent WDTC } \\
\hline Yes & $9(11.4 \%)$ & 5.0 & 0.004 \\
\hline No & $63(79.7 \%)$ & 2.0 & \\
\hline NA & $7(8.9 \%)$ & & \\
\hline \multicolumn{4}{|l|}{ Therapeutic approach } \\
\hline Only symptomatic & $31(39.2 \%)$ & $<1.0$ & \\
\hline Only surgery & $11(13.9 \%)$ & 2.0 & \\
\hline Only RT & $11(13.9 \%)$ & 2.5 & \\
\hline Only CT & $2(2.5 \%)$ & 0.5 & $<0.001$ \\
\hline Only TKI & $3(3.8 \%)$ & 3.0 & \\
\hline $\mathrm{S}+\mathrm{RT}+\mathrm{CT}$ & $6(7.6 \%)$ & 38.5 & \\
\hline $\mathrm{S}+\mathrm{RT}$ & $9(11.4 \%)$ & 5.0 & \\
\hline $\mathrm{S}+\mathrm{CT}$ & $4(5.0 \%)$ & 6.0 & \\
\hline $\mathrm{S}+\mathrm{RT}+\mathrm{CT}+\mathrm{TKI}$ & $2(2.5 \%)$ & 8.0 & \\
\hline$S+T K I$ & $1(1.3 \%)$ & 9.0 & \\
\hline
\end{tabular}

NA, not available; CT, chemotherapy; RT, radiotherapy; S, surgery; TKI, tyrosine kinase inhibitors; WDTC, well-differentiated thyroid cancer.

Anaplastic thyroid cancer incidence

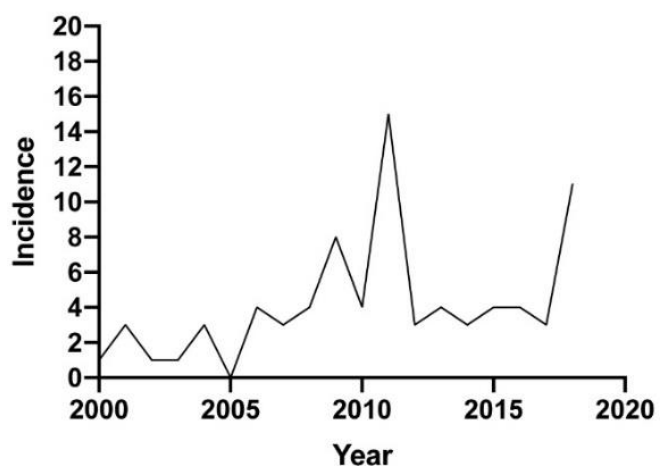

Figure 1. Anaplastic thyroid cancer incidence. 
The majority of patients (86.1\%) presented compressive symptoms: 44 (55.7\%) with dyspnoea, $32(40.5 \%)$ with dysphagia, $20(25.3 \%)$ with dysphonia and $25(31.6 \%)$ complained of local pain; $31(39.2 \%)$ patients had to be submitted to tracheostomy and $2(2.5 \%)$ to tracheal prosthesis insertion; $8(10.1 \%)$ needed a percutaneous endoscopic gastrostomy.

Almost half of the patients (37 $(46.8 \%))$ had a previous history of multinodular goiter. In the histological specimen, nine (11.4\%) patients evidenced a WDTC area; three of these had been followed for a papillary thyroid cancer in the previous years and underwent subsequent dedifferentiation.

At presentation, more than $60 \%$ of the patients presented distant disease. The lungs were the most common site of metastases (45 (57.0\%)), followed by bones $(7(14.3 \%))$ and the brain $(3(4.0 \%))$; in 39 patients $(49 \%)$ only one tissue was affected.

The diagnostic approaches that were offered to our patients are presented in Table 1. Of the $33(41.8 \%)$ patients who were submitted to surgery, resection margins were negative (R0) in $4(12.5 \%)$, microscopic (R1) in 12 (37.5\%) and macroscopic (R2) in 10 (31.3\%). Surgical margins did not have impact on survival: estimated median survival for R0, R1 and R2 patients was 6.0, 8.0 and 3.0 months $(p=0.177)$, respectively (Figure 2). Radiotherapy was offered to $28(35.4 \%)$ patients; median radiation dose was 28.8 (IQR: 46) Gy. Patients who received more than 45 Gy had longer estimated survival: 8.0 vs. 4.0 months, $p=0.020$ (Figure 3). Additionally, seven $(8.8 \%)$ patients were also submitted to radiosensitizing chemotherapy, yet although their estimated survival was higher, it did not reach statistical significance compared to radiotherapy alone ( 6.0 vs. 4.0 months, $p=0.085)$. Altogether, $14(17.7 \%)$ patients were submitted to chemotherapy; the protocols included platin, taxane and/or anthracycline, as recommended by ATA guidelines [4], but the different regimens did not influence survival $(p=0.203)$. TKIs were offered to six $(7.6 \%)$ patients: sorafenib to four, lenvatinib to one and sunitinib after progression with sorafenib to another patient.

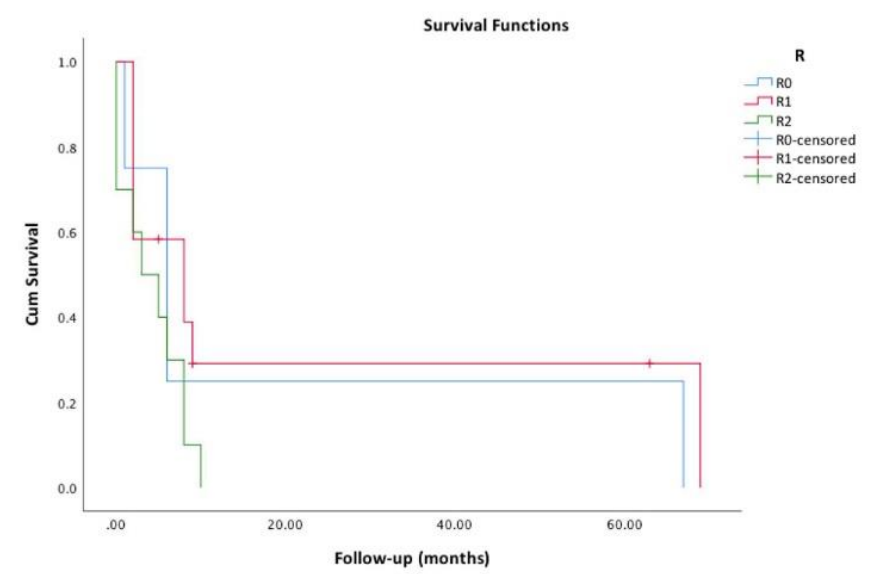

Figure 2. Survival functions regarding surgical margins (R0 vs. R1 vs. R2).

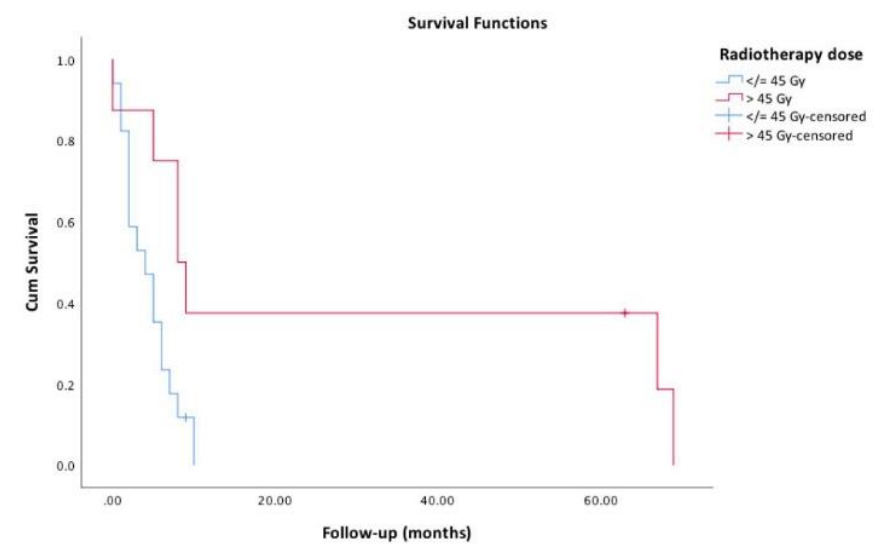

Figure 3. Survival functions regarding radiotherapy dose ( $\leq 45$ Gy vs. $>45$ Gy). 
Median estimate DSS was 2.0 months. However, four (5\%) patients lived longer than one year. All of these were submitted to thyroidectomy with a multimodal approach. One patient remains alive, without evidence of disease, after 63 months of follow-up-he was 60 years old when he was submitted to thyroidectomy (surgery was R1), the tumour had well-differentiated areas, and he was also treated with adjuvant radiotherapy (total dose of $66 \mathrm{~Gy}$ ) and chemotherapy with doxorubicin + docetaxel.

Multivariate analysis is shown in Table 2. Stage IVC, that is, metastatic disease, showed a tendency to influence survival. However, only the therapeutic approaches had a significant impact on overall survival: multimodality therapy with surgery, radiotherapy and chemotherapy/TKI had the greatest impact, providing a risk reduction of $96.9 \%$ of death for each month of follow-up, followed by surgery + radiotherapy, surgery + chemotherapy/TKI, surgery alone, and chemotherapy/TKI and/or radiotherapy, when comparing to isolated symptomatic care.

Table 2. Multivariate analysis.

\begin{tabular}{|c|c|c|c|}
\hline Variables & $\operatorname{Exp}(B)$ & $95 \% \mathrm{CI}$ & $p$-Value \\
\hline Age & 1.005 & $0.974-1.036$ & 0.765 \\
\hline Stage IVB ${ }^{1}$ & 3.098 & $0.865-10.838$ & 0.077 \\
\hline Stage IVC ${ }^{1}$ & 3.327 & $1.001-11.055$ & 0.050 \\
\hline Leukocytosis $^{2}$ & 0.686 & $0.325-1.449$ & 0.324 \\
\hline Histological diagnosis ${ }^{3}$ & 1.265 & $0.746-3.561$ & 0.221 \\
\hline Previous or concomitant WDTC ${ }^{4}$ & 0.719 & $0.351-4.556$ & 0.719 \\
\hline Only surgery ${ }^{5}$ & 0.289 & $0.101-0.828$ & 0.021 \\
\hline Only chemo/TKI and/or RT ${ }^{5}$ & 0.423 & $0.199-0.900$ & 0.026 \\
\hline Surgery $+\mathrm{RT}^{5}$ & 0.108 & $0.034-0.341$ & $<0.001$ \\
\hline Surgery + CT/TKI ${ }^{5}$ & 0.152 & $0.041-0.568$ & 0.005 \\
\hline Surgery + RT + CT/TKI ${ }^{5}$ & 0.031 & $0.005-0.210$ & $<0.001$ \\
\hline
\end{tabular}

${ }^{1}$ Reference: stage IVA $;{ }^{2}$ reference: without leukocytosis; ${ }^{3}$ reference: cytological diagnosis; ${ }^{4}$ reference: without WDTC areas; ${ }^{5}$ reference: only symptomatic therapy. CT, chemotherapy; RT, radiotherapy; $\mathrm{S}$, surgery; TKI, tyrosine kinase inhibitors; WDTC, well-differentiated thyroid cancer.

\section{Discussion}

ATC is an orphan disease that portends a very dismal prognosis. Multimodal approaches that include surgery have the largest impact in improving survival. At our institution, ATC diagnosis has shown a tendency to increase over the years and not to decrease (Figure 1), as observed by other authors $[5,6]$. We observed that our cases continue to be detected at later stages, since only $6.3 \%$ of the patients evidenced thyroid-confined disease at presentation. Accordingly, almost $90 \%$ had compressive symptoms, mainly dyspnoea. Furthermore, $60.8 \%$ had distant metastases at presentation. This is certainly due to the rapid growth typical of these tumours, but we cannot exclude a referral bias, since our hospital is a tertiary care centre. Furthermore, we also admit the unrecognition of the disease by primary and secondary care because almost half of our cohort had a previous history of a long-standing multinodular goiter, which represents a well-recognized risk factor for ATC, especially in elderly patients [3]. As verified by other authors [7,8], lungs were the primary sites of metastases (57\%). Bone came as the second most common affected tissue (14.3\%) which differs from other publications in which intrathoracic lymph nodes were the second most affected distant site. Six patients with IVC stage also showed coexistent well-differentiated areas at histology (data not shown), but we could not assess whether their metastases were from the well-differentiated or from the undifferentiated component.

In our cohort we identified, by univariate analysis, some characteristics that influenced survival: stage at diagnosis, leukocytosis, method of diagnosis, previous or coexistent WDTC and therapeutic approach. On multivariate analysis, despite the tendency for metastatic disease to influence overall survival, only the therapeutic approach had a strong statistical significance. Compared to isolated symptomatic care, surgery alone provided a risk reduction of death of $71.1 \%$, but when combined with radiotherapy or chemotherapy/TKI this reduction was even greater $(89.2 \%$ and $84.8 \%$, respectively). The multimodality approach that included surgery plus radiotherapy and chemotherapy/TKI had the 
most beneficial impact on survival, portending a risk reduction of $96.9 \%$. Interestingly, we verified that the amount of residual disease, either complete (R0 and R1) or incomplete (R2) surgery, did not affect survival. On the other hand, radiation dose of $>45$ Gy provided a longer survival. Neither the used regimens of chemotherapy nor the TKIs were associated with survival, but the number of patients who were submitted to these therapies was small, which hampered the analysis of their individual impact on prognosis. Different prognostic variables have been suggested in ATC. For instance, Glaser et al. [9] analysed the American National Cancer Database (NCDB) and identified total thyroidectomy and high-dose radiotherapy as independent prognostic factors in a cohort of 3552 patients. Lennon et al. [10] studied 64 Irish patients and recognised, as independent negative factors of survival, the presence of distance metastases and palliative care. In a smaller cohort, Machens et al. [11] reported that only nodal status influenced survival. Other authors [12] verified that age $\geq 70$ years, presence of acute symptoms and leukocytosis at initial diagnosis, pT4b tumour, largest tumour dimension $>5 \mathrm{~cm}$ and distant metastases, were all independent predictive factors of poorer survival. A multicentre German study that recently analysed a cohort of 100 ATC patients [13] reported similar demographic and clinicopathological characteristics to our patients; they found that radical surgery with sequential or simultaneous chemotherapy and radiotherapy was associated with survival in IVC patients $(\mathrm{HR}=0.1$, $0.03-0.31, p<0.001)$. However, they noticed that surgery combined with either chemo or radiotherapy alone had no statistically significant benefit compared with surgery alone in their series of IVC patients. Also, in a cohort of 100 patients from Japan, Akaishi and colleagues [14] identified age $\geq 70$ years, leukocytosis, extrathyroid invasion, distant metastases at diagnosis and, with greater impact, complete resection and radiotherapy $\geq 40 \mathrm{~Gy}$, as independent prognostic factors, which is similar to our results. Haymart et al. [15] analysed the overall survival of 2742 ATC patients diagnosed between 1998 and 2008 and concluded that longer survival was associated with a more intensive and multimodal therapy. A study of 95 patients followed at Memorial Sloan-Kettering Cancer Centre [16] verified that in patients with locoregional disease, multimodality treatment with gross total surgical resection and postoperative radiotherapy with or without chemotherapy provided the best local control and had the greatest beneficial impact on DSS.

According to our results and to other reports [14,17-19], including a research by Pezzi and colleagues [17], that enrolled 1288 patients from the American NCDB, radiotherapy with cumulative doses of $>40 / 45$ Gy compared to lower dose regimens provided longer survival.

Only $17 \%$ of our patients were submitted to chemotherapy, making it difficult to draw any conclusion regarding the prognostic significance of this form of therapy. In general, chemotherapy response rates are very low in ATC (15-25\%), bringing only a short period of benefit [20]. Ain et al. [21] reported a phase 2 clinical trial of a 96-h infusion of paclitaxel with the most satisfactory results, showing a total response rate of 53\%. Chemotherapy in the neoadjuvant setting has only been evaluated in small studies (reviewed in [22]). One of these studies [23] investigated the effectiveness of weekly paclitaxel in stage IVB $(n=9)$ and observed a response rate of $33 \%$.

\section{Precision Medicine in ATC: Target and Immune Modulation Therapies}

As also observed in our cohort, ATC has been identified in coexistence with well-differentiated areas, suggesting that these tumours can develop from pre-existing WDTC cases. On the other hand, it has also been hypothesised that these tumours may arise de novo. It has been postulated that the presence of mutated $R A S$ and $B R A F$ in follicular thyroid cancer (FTC) and papillary thyroid cancer (PTC), respectively, in association with later acquired alterations in TP53 and mTOR pathway, might be responsible for this process of dedifferentiation [2,24,25]. Our group has studied the mutational profiles of genes involved in the most deregulated cellular processes and molecular pathways in poorly-differentiated thyroid cancer (PDTC) and ATC [26]. We found that most mutations were present in TP53 and RAS genes. Mutations in CDKs, PIK3CA and PTEN were also present. In a recent study, Kunstman et al. [27] performed whole-exome sequencing in 22 ATC and 4 cell lines, finding the majority of variants clustered in the MAPK, ErbB and RAS signalling pathways. Somatic 
mutations in established thyroid cancer related genes (e.g., BRAF, TP53, RAS, CDKI, PIK3CA) were detected in $64 \%$ of those tumours. In addition, mutations in genes not previously associated with thyroid tumourigenesis were also observed (e.g., mTOR, NF1, NF2, MLH1, MLH3, MSH5 and MSH6). Landa et al. [28] also performed next-generation sequencing (NGS) of 341 cancer genes from 117 patient-derived PDTC and ATC and analysed the transcriptome of a representative subset of 37 tumours and found a high prevalence of TP53, TERT promoter, PI3K/AKT/mTOR pathway effectors, SWI/SNF subunits, and histone methyltransferases, beyond the BRAF and RAS mutations, which were the predominant drivers. The knowledge of the genomic landscape of ATC is becoming very important in clinical practice given that techniques like NGS or liquid biopsies enable a complete somatic analysis in only a few days. Different TKIs that target the abovementioned pathways have been developed and studied in ATC patients.. The mechanisms of action underlying the therapeutic effects of these drugs have been previously reviewed by our group [29] (see Table 3).

Table 3. Tyrosine kinase and immune checkpoint inhibitors studied in ATC.

\begin{tabular}{|c|c|}
\hline TKI or ICI & Targeted Alteration \\
\hline \multicolumn{2}{|c|}{ Recently approved drugs in ATC } \\
\hline $\begin{array}{c}\text { Dabrafenib + trametinib } \\
(150 \mathrm{mg} \text { twice daily }+2 \mathrm{mg} \text { once daily) }\end{array}$ & $\mathrm{BRAF}+\mathrm{MEK}$ \\
\hline Lenvatinib [24 mg daily] & $\begin{array}{l}\text { VEGFR, FGFR, PDGFR- } \alpha \text {, RET, c-kit, KIF5B-RET, } \\
\text { CCDC6-RET, NcoA4-RET rearrangement }\end{array}$ \\
\hline \multicolumn{2}{|c|}{ Drugs studied in ATC } \\
\hline Pembrolizumab & PD-1 \\
\hline Nivolumab & PD-1 \\
\hline Spartalizumab & PD-1 \\
\hline Durvalumab & PD-L1 \\
\hline Tremelimumab & CTLA- 4 \\
\hline Sorafenib & VEGFR, PDGFR- $\beta$, c-kit, RAF, RET, FLT3 \\
\hline Sunitinib & VEGFR, PDGFR, RET, c-kit, FLT3 \\
\hline Vemurafenib & BRAF \\
\hline Crizotinib & ALK, MET, ROS1 \\
\hline Everolimus & mTOR, PI3K \\
\hline Pazopanib & VEGFR, FGFR, PDGFR, c-kit \\
\hline Imatinib & Bcr-Abl, PDGFR, c-kit \\
\hline Gefitinib & EGFR \\
\hline
\end{tabular}

ATC, anaplastic thyroid cancer; TKI, tyrosine kinase inhibitors; ICI, immune checkpoint inhibitors.

Therapy with lenvatinib and sorafenib were approved in WDTC by the Food and Drug Administration (FDA) and by the European Medicines Agency (EMA); however, these TKIs are not currently authorized in ATC by these regulatory agencies. However, lenvatinib was approved in Japan for ATC treatment after a phase II trial (NCT01728623) [30]. In the last year, the FDA approved a $B R A F$ inhibitor (dabrafenib) in combination with a $M E K$ inhibitor (trametinib) for BRAF-mutated ATC, based on a phase II trial (NCT02034110) [31]. The rationale behind this association is that the $M E K$ inhibition prevents the rebound activation of MEK and ERK pathway after BRAF inhibition; this combination results in enhancement of BRAF-MEK-ERK pathway inhibition and anti-tumour activity [32]. Table 3 shows the drugs that have been approved and studied in ATC patients.

Tumour-infiltrating immune cells are present in most solid tumours and can affect the response to therapy and thus clinical outcome. Advances in immune-mediated therapies have evidenced the importance of expanding our understanding of thyroid cancer progression from intrinsic oncogenic pathways to the whole tumour microenvironment. Recently, some studies analysed the presence of certain immune cells, like tumour-associated macrophages, which seem to be prognostic factors in ATC [33]. Chintakuntlawar et al. [34] also investigated the prognostic value of the immune checkpoints programmed death-1 (PD-1) and its ligand (PD-L1) in these tumours and verified that PD-1 and 
PD-L1 are both highly expressed in ATC and are associated with shorter progression-free survival and overall survival in multimodality-treated patients. Different authors have reported the outcomes of distinct immune checkpoint inhibitors on ATC treatment (see Table 4), including pembrolizumab, a monoclonal antibody against PD-1 receptor approved by the FDA in different types of cancer. For instance, Iyer et al. [35] described a cohort of 12 patients with ATC who were treated with pembrolizumab in combination with TKI at the time of progression on TKI; they observed that the addition of pembrolizumab enabled a median overall survival and progression-free survival of 6.93 and 2.96 months, respectively. One year earlier, Kollipara et al. [36] had reported a clinical case of an ATC patient that showed complete remission after treatment with vemurafenib plus nivolumab (therapeutic choices guided by NGS results).

Table 4. Reported results of tyrosine kinase and immune checkpoint inhibitors in ATC.

\begin{tabular}{|c|c|c|c|c|c|}
\hline Authors & Year & TKI or ICI & $\begin{array}{l}\text { No. of ATC } \\
\text { Patients }\end{array}$ & Response & $\begin{array}{l}\text { Median OS and PFS } \\
\text { since TKI/IMT }\end{array}$ \\
\hline Sherman et al. [37] & 2019 & $\begin{array}{l}\text { Durvalumab + } \\
\text { tremelimumab } \\
\qquad(+ \text { SBRT })\end{array}$ & 12 & $\begin{array}{l}\text { ORR: } 0(0 \%) \\
\text { SD: } 1(8 \%)\end{array}$ & OS: 14.5 weeks \\
\hline Harris et al. [38] & 2019 & Everolimus & 5 & $\begin{array}{c}\text { PR: } 1(20 \%), \text { SD: } 2(40 \%) \\
\text { PD: } 1(20 \%)\end{array}$ & OS: $7.4 \mathrm{mo}$ \\
\hline Iyer et al. [20] & 2018 & $\begin{array}{c}\text { Dabrafenib + } \\
\text { trametinib } \\
\text { Lenvatinib }\end{array}$ & $\begin{array}{c}6 \\
10\end{array}$ & $\begin{array}{l}\text { PR: } 3(50 \%) \text {; SD: } 2(33 \%) \\
\text { PR: } 3(30 \%) \text {; SD: } 4(40 \%)\end{array}$ & $\begin{array}{l}\text { OS: } 9.3 \mathrm{mo} \text {; PFS: } 5.2 \mathrm{mo} \\
\text { OS: } 3.9 \mathrm{mo} \text {; PFS: } 2.6 \mathrm{mo}\end{array}$ \\
\hline Iyer et al. [35] & 2018 & $\begin{array}{l}\text { Pembrolizumab } \\
\text { (added to TKI) }\end{array}$ & 12 & $\begin{array}{c}\text { PR: } 5(42 \%) ; \text { SD: } 4(33 \%) \\
\text { PD: } 3(25 \%)\end{array}$ & $\begin{array}{l}\text { OS: } 6.94 \mathrm{mo} \\
\text { PFS: } 2.96 \mathrm{mo}\end{array}$ \\
\hline Wirth et al. [39] & 2018 & Spartalizumab & 30 & $\begin{array}{c}\text { ORR: } 5-6(17-20 \%) \text {, } \\
\text { depending on the criteria }\end{array}$ & \\
\hline Subbiah et al. [31] & 2017 & $\begin{array}{c}\text { Dabrafenib }+ \\
\text { trametinib }\end{array}$ & 16 & ORR: $69 \%$ & \\
\hline Tahara et al. [30] & 2017 & Lenvatinib & 17 & $\begin{array}{c}\text { PR: } 4(24 \%) ; \text { SD: } 12(71 \%) \text {; } \\
\text { PD: } 1(6 \%)\end{array}$ & $\begin{array}{l}\text { OS: } 20.6 \mathrm{mo} \\
\text { PFS: } 7.4 \mathrm{mo}\end{array}$ \\
\hline Ito et al. [40] & 2017 & Sorafenib & 10 & $\begin{array}{c}\text { CR: } 0 \text { (0\%); PR: } 0(0 \%) ; \\
\text { SD: } 4(40 \%)\end{array}$ & $\begin{array}{c}\text { OS: } 5 \mathrm{mo} \\
\text { PFS: } 2.8 \mathrm{mo}\end{array}$ \\
\hline Ravaud et al. [41] & 2017 & Sunitinib & 4 & & $\begin{array}{c}\text { OS: } 5.7 \text { mo } \\
\text { PFS: } 9.8 \text { mo (2 pts) }\end{array}$ \\
\hline Iniguez-Ariza [42] & 2017 & Lenvatinib & 3 & PR: 0 (0\%); SD: 1 (33\%) & OS: $2-7 \mathrm{mo}$ \\
\hline Kollipara et al. [36] & 2017 & $\begin{array}{l}\text { Vemurafenib }+ \\
\text { nivolumab }\end{array}$ & 1 & CR & \\
\hline Hyman et al. [43] & 2016 & Vemurafenib & 7 & $\begin{array}{l}\text { CR: } 1 \text { (14\%); PR: } 1(14 \%) \\
\text { SD: } 0 \text { (0\%); PD: } 4 \text { (57\%) }\end{array}$ & \\
\hline Godbert et al. [44] & 2015 & Crizotinib & 1 & Response $>90 \%$ & \\
\hline Marten et al. [45] & 2015 & Vemurafenib & 1 & PD after 2 mo & \\
\hline Wagle et al. [46] & 2014 & Everolimus & 1 & & $18 \mathrm{mo}$ \\
\hline Lim et al. [47] & 2013 & Everolimus & 6 & PR: $1(17 \%)$ & \\
\hline Savvides et al. [48] & 2013 & Sorafenib & 20 & PR: 2 (10\%); SD: 5 (25\%) & $\begin{array}{l}\text { OS: } 3.9 \mathrm{mo} \\
\text { PFS: } 1.9 \mathrm{mo}\end{array}$ \\
\hline Rosove et al. [49] & 2013 & Vemurafenib & 1 & PR & \\
\hline Bible et al. [50] & 2012 & Pazopanib & 16 & PD: $16(100 \%)$ & $\begin{array}{l}\text { OS: } 111 \text { days } \\
\text { PFS: } 62 \text { days }\end{array}$ \\
\hline Ha et al. [51] & 2010 & Imatinib & 4 & PR: 2 (25\%); SD: 4 (50\%) & $\begin{array}{l}6 \text { mo-OS: } 46 \% \\
6 \text { mo-PFS: } 27 \%\end{array}$ \\
\hline Pennell et al. [52] & 2008 & Gefitinib & 5 & PR: $0(0 \%)$ & \\
\hline
\end{tabular}


The studies analysing the effects of TKI and immune checkpoint inhibitors either isolated or in association are presented in Table 4. In Table 5 we show the clinical trials with these therapies that are currently recruiting or ongoing (www.clinicaltrials.gov; www.clinicaltrialsregister.eu; accessed on 18 May 2019).

Table 5. Currently recruiting and ongoing clinical trials of tyrosine kinase and immune checkpoint inhibitors in ATC.

\begin{tabular}{|c|c|c|c|c|}
\hline Currently Recruiting & & & & \\
\hline Study title & Phase & Drug(s) & Year of start & $\begin{array}{l}\text { Estimated year of } \\
\text { completion }\end{array}$ \\
\hline $\begin{array}{l}\text { Trametinib in combination with paclitaxel } \\
\text { in the treatment of ATC NCT03085056 }\end{array}$ & I & $\begin{array}{l}\text { Trametinib } \\
\text { Paclitaxel }\end{array}$ & 2017 & 2020 \\
\hline $\begin{array}{l}\text { A phase II study of MLN0128 in } \\
\text { metastatic ATC NCT02244463 }\end{array}$ & II & MLN0128 & 2014 & 2022 \\
\hline $\begin{array}{l}\text { Nexavar for neoadjuvant treatment of } \\
\text { ATC NCT03565536 }\end{array}$ & II & Sorafenib & 2018 & 2019 \\
\hline $\begin{array}{l}\text { Pembrolizumab in } \\
\text { anaplastic/undifferentiated thyroid cancer } \\
\text { NCT02688608 }\end{array}$ & II & Pembrolizumab & 2016 & 2020 \\
\hline $\begin{array}{l}\text { Ceritinib in mutation and oncogene } \\
\text { directed therapy in thyroid cancer } \\
\text { NCT02289144 }\end{array}$ & II & Ceritinib & 2014 & 2021 \\
\hline $\begin{array}{l}\text { Nivolumab plus ipilimumab in thyroid } \\
\text { cancer NCT03246958 }\end{array}$ & II & $\begin{array}{l}\text { Nivolumab } \\
\text { Ipilimumab }\end{array}$ & 2017 & 2025 \\
\hline $\begin{array}{l}\text { Atezolizumab with chemotherapy in } \\
\text { treating patients with anaplastic or poorly } \\
\text { differentiated thyroid cancer } \\
\text { NCT } 03181100\end{array}$ & II & $\begin{array}{l}\text { Atezolizumab } \\
\text { Bevacizumab } \\
\text { Cobimetinib } \\
\text { Nab-paclitaxel } \\
\text { Paclitaxel } \\
\text { Vemurafenib }\end{array}$ & 2017 & 2023 \\
\hline \multicolumn{5}{|l|}{ Ongoing } \\
\hline $\begin{array}{l}\text { Phase II study assessing the efficacy and } \\
\text { safety of lenvatinib for ATC NCT02726503 }\end{array}$ & II & Lenvatinib & 2016 & 2020 \\
\hline $\begin{array}{l}\text { Immunotherapy and stereotactic body } \\
\text { radiotherapy (SBRT) for metastatic ATC } \\
\text { NCT03122496 }\end{array}$ & I & $\begin{array}{l}\text { Durvalumab } \\
\text { Tremelimumab } \\
\text { SBRT }\end{array}$ & 2017 & 2020 \\
\hline $\begin{array}{l}\text { Pembrolizumab, chemotherapy and } \\
\text { radiation therapy with or without surgery } \\
\text { in treating patients with ATC } \\
\text { NCT03211117 }\end{array}$ & II & $\begin{array}{c}\text { Docetaxel } \\
\text { Doxorrubicin } \\
\text { hydrochloride } \\
\text { IMRT } \\
\text { Pembrolizumab }\end{array}$ & 2017 & 2019 \\
\hline $\begin{array}{l}\text { Phase I/II study of PDR001 in patients } \\
\text { with advanced malignancies } \\
\text { NCT02404441 }\end{array}$ & $\begin{array}{l}\text { I } \\
\text { II }\end{array}$ & PDR001 & 2015 & 2020 \\
\hline $\begin{array}{l}\text { Intensity-modulated radiation therapy } \\
\text { and paclitaxel with or without pazopanib } \\
\text { hydrochloride in treating patients with } \\
\text { anaplastic thyroid cancer NCT01236547 }\end{array}$ & II & $\begin{array}{l}\text { IMRT Paclitaxel } \\
\text { Pazopanib } \\
\text { hydrochloride }\end{array}$ & 2010 & 2019 \\
\hline $\begin{array}{l}\text { Pazopanib hydrochloride in treating } \\
\text { patients with advanced thyroid cancer } \\
\text { NCT00625846 }\end{array}$ & II & $\begin{array}{c}\text { Pazopanib } \\
\text { hydrochloride }\end{array}$ & 2008 & \\
\hline $\begin{array}{l}\text { Treatment with recombinant human } \\
\text { Interleukin } 1 \text { receptor antagonist } \\
\text { (Anakinra) in patients with anaplastic } \\
\text { thyroid cancer: a proof of concept study } \\
\text { EudraCT: 2017-003028-59 }\end{array}$ & IV & $\begin{array}{c}\text { Interleukin } 1 \\
\text { receptor antagonist }\end{array}$ & 2018 & \\
\hline
\end{tabular}


Table 5. Cont.

\begin{tabular}{|c|c|c|c|c|}
\hline Currently Recruiting & & & & \\
\hline Study title & Phase & Drug(s) & Year of start & $\begin{array}{c}\text { Estimated year of } \\
\text { completion }\end{array}$ \\
\hline $\begin{array}{l}\text { A phase II study to investigate the efficacy } \\
\text { of RAD001 (Afinitor }{ }^{\circledR} \text {, everolimus) in } \\
\text { patients with irresectable recurrent or } \\
\text { metastatic differentiated, undifferentiated } \\
\text { (anaplastic) and medullary thyroid } \\
\text { carcinoma EudraCT: 2009-016669-27 }\end{array}$ & II & Everolimus & 2010 & \\
\hline $\begin{array}{l}\text { An open-label phase } 2 \text { multi-cohort trial } \\
\text { of nivolumab in advanced or metastatic } \\
\text { malignancies EudraCT: } 2016-000461-23\end{array}$ & II & nivolumab & 2017 & \\
\hline
\end{tabular}

\section{Conclusions}

The present study reflects the largest experience with ATC in the country and is one of the largest reported in Europe. One limitation is its retrospective nature, which makes it difficult to retrieve data not stated in clinical files, but this problem is similar to the majority of the studies reported with this type of cancer.

The major issue about ATC, apart from the lack of effective therapeutic options, is that the great majority of patients join the reference centres at an advanced stage of disease. Thus, it is urgent to improve and speed up the recognition and referral of these aggressive cases to tertiary or oncological centres so that they can be promptly managed by a multidisciplinary team that offers a multimodality treatment, which is often complex and needs to be held at an institution with expertise in ATC. Recently, Cabanillas et al. [53] implemented at their centre a new process flow for patients with ATC, allowing their immediate schedule, which resulted in a $98 \%$ decrease in referral to disposition time and led to a significant increase in ATC referrals to their institution.

In conclusion, ATC management is very challenging, and prospective trials are needed, with clinical criteria that may be adjusted to the real ATC patients, who are usually old and with an advanced stage of disease. Multimodality approach with surgery, radiotherapy and chemotherapy, either conventional or with the new agents, may offer the best chances for survival enhancement.

Author Contributions: J.S.-P. planned the study, collected the data, performed the statistical analysis and wrote the manuscript; R.C. collected the data and performed the statistical analysis; E.L. provided the collected ATC cases and reviewed the manuscript; V.L. planned and supervised the study and reviewed the manuscript.

Funding: This research received no external funding.

Acknowledgments: The authors are thankful for the collaboration of the Endocrinology and Pathology Departments, from Instituto Português de Oncologia de Lisboa Francisco Gentil (IPOLFG), Lisboa, Portugal.

Conflicts of Interest: The authors have no conflicts of interests.

\section{References}

1. Ragazzi, M.; Ciarrocchi, A.; Sancisi, V.; Bisagni, A.; Piana, S. Update on anaplastic thyroid carcinoma: Morphological, molecular, and genetic features of the most aggressive thyroid cancer. Int. J. Endocrinol. 2014, 2014, 79083. [CrossRef] [PubMed]

2. Smallridge, R.C.; Marlow, L.A.; Copland, J.A. Anaplastic thyroid cancer: Molecular pathogenesis and emerging therapies. Endocr. Relat. Cancer 2009, 16, 17-44. [CrossRef] [PubMed]

3. Molinaro, E.; Romei, C.; Biagini, A.; Sabini, E.; Agate, L.; Mazzeo, S.; Materazzi, G.; Sellari-Franceschini, S.; Ribechini, A.; Torregrossa, L.; et al. Anplastic thyroid carcinoma: From clinicopathology to genetics and advanced therapies. Nat. Rev. Endocrinol. 2017, 13, 644-660. [CrossRef] [PubMed] 
4. Smallridge, R.C.; Ain, K.B.; Asa, S.L.; Bible, K.C.; Brierley, J.D.; Burman, K.D.; Kebebew, E.; Lee, N.Y.; Nikiforov, Y.E.; Shah, M.H.; et al. American Thyryoid Association Anaplastic Thyroid Cancer Guidelines Taskforce. American Thyroid Association guidelines for management of patients with anaplastic thyroid cancer. Thyroid 2012, 22, 1104-1139. [CrossRef] [PubMed]

5. Davies, L.; Welch, H.G. Increasing incidence of thyroid cancer in the United States, 1973-2002. J. Am. Med. Assoc. 2006, 295, 2164-2167. [CrossRef] [PubMed]

6. Dijkstra, B.; Prichard, R.S.; Lee, A.; Kelly, L.M.; Smyth, P.P.; Crotty, T.; McDermott, E.W.; Hill, A.D.; O'Higgins, N. Changing patterns of thyroid carcinoma. Ir. J. Med. Sci. 2007, 176, 87-90. [CrossRef] [PubMed]

7. Besic, N.; Gazic, B. Sites of Metastases of Anaplastic Thyroid Carcinoma: Autopsy Findings in 45 Cases from a Single Institution. Thyroid 2013, 23, 709-713. [CrossRef]

8. Ibanez, M.L.; Russell, W.O.; Albores-Saavedra, J.; Lampertico, P.; White, E.C.; Clark, R.L. Thyroid carcinoma-Biologic behavior and mortality. Postmortem findings in 42 cases, including 27 in which the disease was fatal. Cancer 1966, 19, 1039-1052. [CrossRef]

9. Glaser, S.M.; Mandish, S.F.; Gill, B.S.; Balasubramani, G.K.; Clump, D.A.; Beriwal, S. Anaplastic thyroid cancer: Prognostic factors, patterns of care, and overall survival. Head Neck 2016, 38, E2083-E2090. [CrossRef]

10. Lennon, P.; Deady, S.; Healy, M.L.; Toner, M.; Kinsella, J.; Timon, C.I.; O’Neill, J.P. Anaplastic thyroid carcinoma: Failure of conventional therapy but hope of targeted therapy. Head Neck 2016, 38, E1122-E1129. [CrossRef]

11. Machens, A.; Hinze, R.; Lautenschläger, C.; Thomusch, O.; Dunst, J.; Dralle, H. Extended surgery and early postoperative radiotherapy for undifferentiated thyroid carcinoma. Thyroid 2001, 11, 373-380. [CrossRef] [PubMed]

12. Sugitani, I.; Miyauchi, A.; Sugino, K.; Okamoto, T.; Yoshida, A.; Suzuki, S. Prognostic factors and treatment outcomes for anaplastic thyroid carcinoma: ATC Research Consortium of Japan cohort study of 677 patients. World J. Surg. 2012, 36, 1247-1254. [CrossRef] [PubMed]

13. Wendler, J.; Kroiss, M.; Gast, K.; Kreissl, M.C.; Allelein, S.; Lichtenauer, U.; Blaser, R.; Spitzweg, C.; Fassnacht, M.; Schott, M.; et al. Clinical presentation, treatment and outcome of anaplastic thyroid carcinoma: Results of a multicentre study in Germany. Eur. J. Endocrinol. 2016, 175, 521-529. [CrossRef] [PubMed]

14. Akaishi, J.; Sugino, K.; Kitagawa, W.; Nagahama, M.; Kameyama, K.; Shimizu, K.; Ito, K. Prognostic factors and treatment outcomes of 100 cases of anaplastic thyroid carcinoma. Thyroid 2011, 21, 1183-1189. [CrossRef] [PubMed]

15. Haymart, M.R.; Banerjee, M.; Yin, H.; Worden, F.; Griggs, J.J. Marginal treatment benefit in anaplastic thyroid cancer. Cancer 2013, 119, 3133-3139. [CrossRef]

16. Mohebati, A.; Dilorenzo, M.; Palmer, F.; Patel, S.G.; Pfister, D.; Lee, N.; Tuttle, R.M.; Shaha, A.R.; Shah, J.P.; Ganly, I. Anaplastic thyroid carcinoma: A 25-year single-institution experience. Ann. Surg. Oncol. 2014, 21, 1665-1670. [CrossRef] [PubMed]

17. Pezzi, T.A.; Mohamed, A.S.R.; Sheu, T.; Blanchard, P.; Sandulache, V.C.; Lai, S.Y.; Cabanillas, M.E.; Williams, M.D.; Pezzi, C.M.; Lu, C.; et al. Radiation therapy dose is associated with improved survival for unresected anaplastic thyroid carcinoma: Outcomes from the National CancerData Base. Cancer 2017, 123, 1653-1661. [CrossRef]

18. Sun, C.; Li, Q.; Hu, Z.; He, J.; Li, C.; Li, G.; Tao, X.; Yang, A. Treatment and prognosis of anaplastic thyroid carcinoma: Experience from a single institution in China. PLoS ONE 2013, 8, e80011. [CrossRef]

19. Dumke, A.K.; Pelz, T.; Vordermark, D. Long-term results of radiotherapy in anaplastic thyroid cancer. Radiat. Oncol. 2014, 9, 90. [CrossRef]

20. Iyer, P.C.; Dadu, R.; Ferrarotto, R.; Busaidy, N.L.; Habra, M.A.; Zafereo, M.; Gross, N.; Hess, K.R.; Gule-Monroe, M.; Williams, M.D.; et al. Real-World Experience with Targeted Therapy for the Treatment of Anaplastic Thyroid Carcinoma. Thyroid 2018, 28, 79-87. [CrossRef]

21. Ain, K.B.; Egorin, M.J.; DeSimone, P.A. Treatment of anaplastic thyroid carcinoma with Paclitaxel: Phase 2 trial using ninety-six-hour infusion. Thyroid 2000, 10, 587-594. [CrossRef] [PubMed]

22. Cabanillas, M.E.; Zafereo, M.; Gunn, G.B.; Ferrarotto, R. Anaplastic Thyroid Carcinoma: Treatment in the Age of Molecular Targeted Therapy. J. Oncol. Pract. 2016, 12, 511-518. [CrossRef] [PubMed]

23. Higashiyama, T.; Ito, Y.; Hirokawa, M.; Fukushima, M.; Uruno, T.; Miya, A.; Matsuzuka, F.; Miyauchi, A. Induction chemotherapy with weekly paclitaxel administration for anaplastic thyroid carcinoma. Thyroid 2010, 20, 7-14. [CrossRef] [PubMed] 
24. Kondo, T.; Ezzat, S.; Asa, S.L. Pathogenetic mechanisms in thyroid follicular-cell neoplasia. Nat. Rev. Cancer 2006, 6, 292-306. [CrossRef] [PubMed]

25. Nikiforov, Y.E.; Nikiforova, M.N. Molecular genetics and diagnosis of thyroid cancer. Nat. Rev. Endocrinol. 2011, 7, 569-580. [CrossRef] [PubMed]

26. Pita, J.M.; Banito, A.; Cavaco, B.M.; Leite, V. Gene expression profiling associated with the progression to poorly differentiated thyroid carcinomas. Br. J. Cancer 2009, 101, 1782-1791. [CrossRef] [PubMed]

27. Kunstman, J.W.; Juhlin, C.C.; Goh, G.; Brown, T.C.; Stenman, A.; Healy, J.M.; Rubinstein, J.C.; Choi, M.; Kiss, N.; Nelson-Williams, C.; et al. Characterization of the mutational landscape of anaplastic thyroid cancer via whole-exome sequencing. Hum. Mol. Genet. 2015, 24, 2318-2329. [CrossRef] [PubMed]

28. Landa, I.; Ibrahimpasic, T.; Boucai, L.; Sinha, R.; Knauf, J.A.; Shah, R.H.; Dogan, S.; Ricarte-Filho, J.C.; Krishnamoorthy, G.P.; Xu, B.; et al. Genomic and transcriptomic hallmarks of poorly differentiated and anaplastic thyroid cancers. J. Clin. Investig. 2016, 126, 1052-1066. [CrossRef] [PubMed]

29. Donato, S.; Santos, R.; Simões, H.; Leite, V. Novel therapies against aggressive differentiated thyroid carcinomas. Int. J. Endocr. Oncol. 2018, 5. [CrossRef]

30. Tahara, M.; Kiyota, N.; Yamazaki, T.; Chayahara, N.; Nakano, K.; Inagaki, L.; Toda, K.; Enokida, T.; Minami, H.; Imamura, Y.; et al. Lenvatinib for Anaplastic Thyroid Cancer. Front. Oncol. 2017, 7, 25. [CrossRef] [PubMed]

31. Subbiah, V.; Kreitman, R.J.; Wainberg, Z.A.; Cho, J.Y.; Schellens, J.H.M.; Soria, J.C.; Wen, P.Y.; Zielinski, C.; Cabanillas, M.E.; Urbanowitz, G.; et al. Dabrafenib and Trametinib Treatment in Patients with Locally Advanced or Metastatic BRAF V600-Mutant Anaplastic Thyroid Cancer. J. Clin. Oncol. 2017, 36, 7-13. [CrossRef] [PubMed]

32. Lito, P.; Pratilas, C.A.; Joseph, E.W.; Tadj, M.; Halilovic, E.; Zubrowski, M.; Huang, A.; Wong, W.L.; Callahan, M.K.; Merghoub, T.; et al. Relief of profound feedback inhibition of mitogenic signaling by RAF inhibitors attenuates their activity in BRAFV600E melanomas. Cancer Cell 2012, 22, 668-682. [CrossRef] [PubMed]

33. Ryder, M.; Ghossein, R.A.; Ricarte-Filho, J.C.; Knauf, J.A.; Fagin, J.A. Increased density of tumor-associated macrophages is associated with decreased survival in advanced thyroid cancer. Endocr. Relat. Cancer 2008, 15, 1069-1074. [CrossRef] [PubMed]

34. Chintakuntlawar, A.V.; Rumilla, K.M.; Smith, C.Y.; Jenkins, S.M.; Foote, R.L.; Kasperbauer, J.L.; Morris, J.C.; Ryder, M.; Alsidawi, S.; Hilger, C.; et al. Expression of PD-1 and PD-L1 in Anaplastic Thyroid Cancer Patients Treated with Multimodal Therapy: Results from a Retrospective Study. J. Clin. Endocrinol. Metab. 2017, 102, 1943-1950. [CrossRef] [PubMed]

35. Iyer, P.C.; Dadu, R.; Gule-Monroe, M.; Busaidy, N.L.; Ferrarotto, R.; Habra, M.A.; Zafereo, M.; Williams, M.D.; Gunn, G.B.; Grosu, H.; et al. Salvage pembrolizumab added to kinase inhibitor therapy for the treatment of anaplastic thyroid carcinoma. J. Immunother. Cancer 2018, 11, 68. [CrossRef]

36. Kollipara, R.; Schneider, B.; Radovich, M.; Babu, S.; Kiel, P.J. Exceptional Response with Immunotherapy in a Patient with Anaplastic Thyroid Cancer. Oncologist 2017, 22, 1149-1151. [CrossRef] [PubMed]

37. Sherman, E.J.; Tsai, C.J.; Zhi, W.I.; Fetten, J.V.; Wu, V.; Ho, A.L.; Riaz, N.; Pfister, D.G.; Lee, N.Y. Pilot study combining PD-L1 antibody durvalumab (D) with CTLA-4 antibody tremelimumab (T) and stereotactic body radiotherapy (SBRT) to treat metastatic anaplastic thyroid cancer (ATC). J. Clin. Oncol. 2019, 37 (Suppl. S15). [CrossRef]

38. Harris, E.J.; Hanna, G.J.; Chau, N.; Rabinowits, G.; Haddad, R.; Margalit, D.N.; Schoenfeld, J.; Tishler, R.B.; Barletta, J.A.; Nehs, M.; et al. Everolimus in Anaplastic Thyroid Cancer: A Case Series. Front. Oncol. 2019, 9, 106. [CrossRef] [PubMed]

39. Wirth, L.J.E.E.; Capdevila, J.; Paz-Ares, L.G.; Lin, C.; Taylor, M.H.; Ramlau, R.; Butler, M.; Delord, J.P.; Horvath, Z.; Gelderblom, H.; et al. Phase I/II study of spartalizumab (PDR001), an anti-PD1 mAb, in patients with anaplastic thyroid cancer. J. Clin. Oncol. 2018, 36 (Suppl. S15). [CrossRef]

40. Ito, Y.; Onoda, N.; Ito, K.; Sugitani, I.; Takahashi, S.; Yamaguchi, I.; Kabu, K.; Tsukada, K. Sorafenib in Japanese patients with locally advanced or metastatic medullary thyroid carcinoma and anaplastic thyroid carcinoma. Thyroid 2017, 27, 1142-1148. [CrossRef] [PubMed]

41. Ravaud, A.; De la Fouchardière, C.; Caron, P.; Doussau, A.; Do Cao, C.; Asselineau, J.; Rodien, P.; Pouessel, D.; Nicolli-Sire, P.; Klein, M.; et al. A multicenter phase II study of sunitinib in patients with locally advanced or metastatic differentiated, anaplastic or medullary thyroid carcinomas: Mature data from the THYSU study. Eur. J. Cancer 2017, 76, 110-117. [CrossRef] [PubMed] 
42. Iniguez-Ariza, N.M.; Ryder, M.M.; Hilger, C.R.; Bible, K.C. Salvage Lenvatinib therapy in metastatic anaplastic thyroid Cancer. Thyroid 2017, 27, 923-927. [CrossRef] [PubMed]

43. Hyman, D.M.; Puzanov, I.; Subbiah, V.; Faris, J.E.; Chau, I.; Blay, J.Y.; Wolf, J.; Raje, N.S.; Diamond, E.L.; Hollebecque, A.; et al. Vemurafenib in multiple nonmelanoma cancers with BRAF V600 mutations. N. Engl. J. Med. 2015, 373, 726-736. [CrossRef] [PubMed]

44. Godbert, Y.; Henriques de Figueiredo, B.; Bonichon, F.; Chibon, F.; Hostein, I.; Perot, G.; Dupin, C.; Daubech, A.; Belleannee, G.; Gros, A.; et al. Remarkable response to crizotinib in woman with anaplastic lymphoma kinase-rearranged anaplastic thyroid carcinoma. J. Clin. Oncol. 2015, 33, 84-87. [CrossRef] [PubMed]

45. Marten, K.A.; Gudena, V.K. Use of vemurafenib in anaplastic thyroid carcinoma: A case report. Cancer Biol. Ther. 2015, 16, 1430-1433. [CrossRef] [PubMed]

46. Wagle, N.; Grabiner, B.C.; Van Allen, E.M.; Amin-Mansour, A.; Taylor-Weiner, A.; Rosenberg, M.; Gray, N.; Barletta, J.A.; Guo, Y.; Swanson, S.J.; et al. Response and acquired resistance to everolimus in anaplastic thyroid cancer. N. Engl. J. Med. 2014, 371, 1426-1433. [CrossRef] [PubMed]

47. Lim, S.M.; Chang, H.; Yoon, M.J.; Hong, Y.K.; Kim, H.; Chung, W.Y.; Park, C.S.; Nam, K.H.; Kang, S.W.; Kim, M.K.; et al. A multicenter, phase II trial of everolimus in locally advanced or metastatic thyroid cancer of all histologic subtypes. Ann. Oncol. 2013, 24, 3089-3094. [CrossRef] [PubMed]

48. Savvides, P.; Nagaiah, G.; Lavertu, P.; Fu, P.; Wright, J.J.; Chapman, R.; Wasman, J.; Dowlati, A.; Remick, S.C. Phase II trial of sorafenib in patients with advanced anaplastic carcinoma of the thyroid. Thyroid 2013, 23, 600-604. [CrossRef]

49. Rosove, M.H.; Peddi, P.F.; Glaspy, J.A. BRAF V600E inhibition in anaplastic thyroid cancer. N. Engl. J. Med. 2013, 368, 684-685. [CrossRef]

50. Bible, K.C.; Suman, V.J.; Menefee, M.E.; Smallridge, R.C.; Molina, J.R.; Maples, W.J.; Karlin, N.J.; Travnor, A.M.; Kumar, P.; Goh, B.C.; et al. Mayo Phase 2 Consortium; Mayo Clinic Endocrine Malignances Disease Oriented Group. A multiinstitutional phase 2 trial of pazopanib monotherapy in advanced anaplastic thyroid cancer. J. Clin. Endocrinol. Metab. 2012, 97, 3179-3184. [CrossRef]

51. Ha, H.T.; Lee, J.S.; Urba, S.; Koenig, R.J.; Sisson, J.; Giordano, T.; Worden, F.P. A phase II study of imatinib in patients with advanced anaplastic thyroid cancer. Thyroid 2010, 20, 975-980. [CrossRef] [PubMed]

52. Pennell, N.A.; Daniels, G.H.; Haddad, R.I.; Ross, D.S.; Evans, T.; Wirth, L.J.; Fidias, P.H.; Temel, J.S.; Gurubhagavatula, S.; Heist, R.S.; et al. A phase II study of gefitinib in patients with advanced thyroid cancer. Thyroid 2008, 18, 317-323. [CrossRef] [PubMed]

53. Cabanillas, M.E.; Williams, M.D.; Gunn, G.B.; Weitzman, S.P.; Burke, L.; Busaidy, N.L.; Ying, A.K.; Yiin, Y.H.; William, W.N.; Lu, C.; et al. Facilitating anaplastic thyroid cancer specialized treatment: A model for improving access to multidisciplinary care for patients with anaplastic thyroid cancer. Head Neck 2017, 39, 1291-1295. [CrossRef] [PubMed]

(C) 2019 by the authors. Licensee MDPI, Basel, Switzerland. This article is an open access article distributed under the terms and conditions of the Creative Commons Attribution (CC BY) license (http://creativecommons.org/licenses/by/4.0/). 